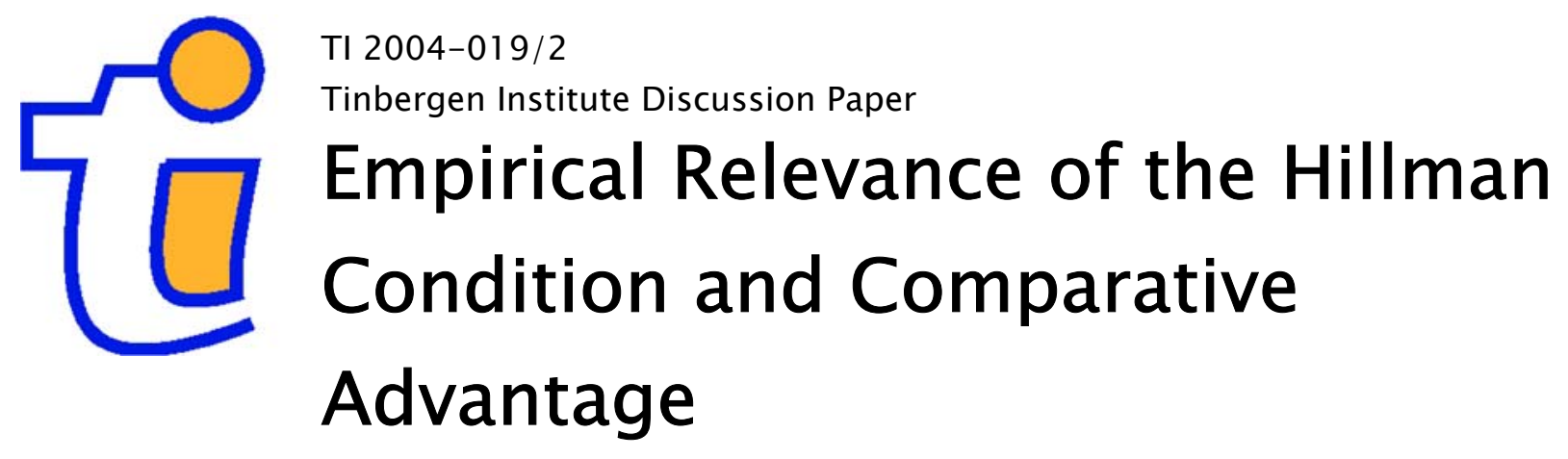

Jeroen Hinloopen'

Charles van Marrewijk²

${ }^{1}$ Department of Economics, Universiteit van Amsterdam, ENCORE, and Tinbergen Institute,

2 Department of Economics, Erasmus Universiteit Rotterdam, and Tinbergen Institute. 


\section{Tinbergen Institute}

The Tinbergen Institute is the institute for economic research of the Erasmus Universiteit Rotterdam, Universiteit van Amsterdam, and Vrije Universiteit Amsterdam.

Tinbergen Institute Amsterdam

Roetersstraat 31

1018 WB Amsterdam

The Netherlands

Tel.: $\quad+31(0) 205513500$

Fax: $\quad+31(0) 205513555$

Tinbergen Institute Rotterdam

Burg. Oudlaan 50

3062 PA Rotterdam

The Netherlands

Tel.: $\quad+31(0) 104088900$

Fax: $\quad+31(0) 104089031$

Please send questions and/or remarks of nonscientific nature to driessen@tinbergen.nl.

Most TI discussion papers can be downloaded at http://www.tinbergen.nl. 


\title{
Empirical relevance of the Hillman condition and comparative advantage ${ }^{1}$
}

\author{
Jeroen Hinloopen ${ }^{2}$ \\ University of Amsterdam (and Tinbergen Institute) \\ and
}

Economics Network for Competition and Regulation (ENCORE)

Charles van Marrewijk ${ }^{3}$

Erasmus University Rotterdam (and Tinbergen Instituut)

February 2004

\begin{abstract}
$\underline{\text { Abstract }}$
We analyze the empirical violation of the Hillman condition, a necessary and sufficient condition for the correspondence between comparative advantage and pre-trade relative prices. Our comprehensive data set allows us to investigate the Hillman condition for virtually all countries of the world, over an extended period of time, for many sectors, and for different levels of aggregation. Violations of the Hillman condition are small as a share of the number of observations, but can be substantial as a share of the value of world exports. Measured either way, violations occurred much more frequently in the 1970s and early 1980s, a difference mostly caused by the two oil crises. As the condition is useful for identifying various anomalies, we argue that it should be included as a standard diagnostic test for empirical studies into comparative advantage.
\end{abstract}

Keywords: Balassa index, Hillman condition, comparative advantage

JEL codes: C81, D43, F11, F20

(C) Hinloopen and van Marrewijk, 2004

\footnotetext{
${ }^{1}$ We would like to thank Joe Francois for useful comments. Any errors are, of course, our own.

${ }^{2}$ Correspondence: University of Amsterdam, Department of Economics, Roetersstraat 11, 1018 WB Amsterdam; J.Hinloopen@uva.nl.; www.fee.uva.nl/io/jhinloopen.

${ }^{3}$ Correspondence: Erasmus University Rotterdam, Department of Economics, Burgemeester Oudlaan 50, 3062 PA Rotterdam; vanmarrewijk@few.eur.nl; www.few.eur.nl/few/people/vanmarrewijk.
} 


\section{Introduction}

The concept of 'revealed' comparative advantage, introduced by Liesner (1958) but refined and popularized by Balassa (1965) and therefore known as the 'Balassa index', is widely used empirically to identify a country's weak and strong export sectors. Porter (1990) uses it to identify strong sectoral clusters, Amiti (1999) analyzes specialization patterns in Europe, Proudman and Redding $(1998,2000)$ focus on the dynamics of comparative advantage, Bojnec (2001) analyzes agricultural trade, Hinloopen and Van Marrewijk (2001) study the (dynamics of the) empirical distribution of European trade, and Fertö and Hubbard (2003) analyze competitiveness in Hungarian agrifood sectors. The theoretical basis for the Balassa index as an indicator of comparative advantage was provided by Hillman (1980), who diagrammatically developed a necessary and sufficient condition under homothetic preferences for the correspondence between the Balassa index and pre-trade relative prices in cross-country comparisons for a specific sector. Hillman's condition can be easily verified empirically, which makes it rather surprising that it is completely ignored by the large majority of the empirical studies on revealed comparative advantage. In fact, Marchese and Nadal De Simone (1989), who analyze the exports of 118 developing countries in 1985 at the 1-, 3-, 4-, and 5-digit level, provide the only thorough empirical investigation of the Hillman condition we are aware of. ${ }^{4}$ They conclude that the Hillman condition does not hold in the year 1985 for about 9.5 percent of the value of exports of their group of developing countries. In our study of monthly EU exports to Japan in the period 1992-96, Hinloopen and Van Marrewijk (2001) find that the Hillman condition does not hold for about 7.0 percent of the value of exports, or about 0.5 percent of the number of observations. ${ }^{5}$ In this study we find a similar dispersion between the importance of the Hillman condition in terms of the value of exports compared to the number of sectors.

This paper investigates the empirical violation of the Hillman condition using the Hinloopen and Van Marrewijk (2004) data set, which is based on the Feenstra (2000) data set. We have annual observations on bilateral trade flows for 1,056 4digit sectors, 183 countries, and 28 years, with a total of slightly less than 18.4 million positive observations. It allows us to thoroughly investigate the Hillman condition for virtually all countries of the world, over an extended period of time, for many sectors, and for different levels of aggregation. We find that for the period as a whole the Hillman condition is violated on average for less than 4 percent of the value of exports and fewer than 0.2 percent of the number of observations. We also find that 1985, the year analyzed by Marchese and Nadal De Simone (1989), is not

\footnotetext{
${ }^{4}$ It is not entirely clear to us why they do not investigate their data set at the 2-digit level.

${ }^{5}$ Marchese and Nadal De Simone (1989) use the 118 developing countries as reference countries, while Hinloopen and Van Marrewijk (2001) use the EU countries as reference countries.
} 
representative of the degree to which the Hillman condition is met. Indeed, we find considerable fluctuation over time with high violations in the period 1970-84 and low violations in the period 1988-97. The relationship between violations of the Hillman condition and sector aggregation is clear regarding the number of observations, but not so clear regarding the value of exports. An overview of the sectors for which the Hillman condition is violated and a brief investigation into its link with aggregation issues reveals that the condition is rather useful in identifying anomalies. We therefore argue that it would be wise for empirical studies into comparative advantage to henceforth include an empirical evaluation of the Hillman condition as a standard diagnostic test. The next section briefly discusses the Balassa index, the Hillman condition and some methodological issues. Section 3 gives an overview of violations of the Hillman condition. Section 4 analyzes the connections between sectors and countries in more detail. Section 5 focuses on a methodological aggregation issue, and section 6 concludes.

\section{The Balassa index, the Hillman condition, and methodology}

As it is hard to gauge the importance of a sector without a frame of reference, Balassa (1965) introduced normalized export shares as an indicator of revealed comparative advantage:

$$
B I_{i, t}^{j}=\frac{\text { share industry } j \text { in country } i \text { 's export, period } t}{\text { share industry } j \text { in reference countries 's export, period } t} .
$$

If the Balassa index is above unity, that is $B I_{i, t}^{j}>1$, country $i$ is said to have a revealed comparative advantage in the production of commodity $j$ in time period $t$ relative to the group of reference countries, as its export share for product $j$ is larger than the concomittant export share in the reference countries. The group of reference countries may vary, as indeed it does in the studies mentioned above, but is most often determined by the largest set of countries for which the researcher has reliable data available for the study at hand.

Hillman's condition focuses on the correspondence between the Balassa index and pre-trade relative prices in cross-country comparisons for a specific sector under homothetic preferences by forming a Hicksian composite commodity for all other sectors. As the transformation performed on the Balassa index has to be monotonic, Hillman's condition can be interpreted as a monotonicity condition for scaling a country's exports by a measure of its (sector) size. More specifically, let $X_{i, t}^{j}$ be the exports of sector $j$, country $i$ in period $t$. Hillman's condition is then given by:

(2) $\quad 1-\frac{X_{i, t}^{j}}{\sum_{i} X_{i, t}^{j}}>\frac{X_{i, t}^{j}}{\sum_{j} X_{i, t}^{j}}\left(1-\frac{\sum_{j} X_{i, t}^{j}}{\sum_{i} \sum_{j} X_{i, t}^{j}}\right)$ 
Evidently, the condition can be easily verified empirically as it requires only (aggregation of) data on exports for different sectors. Three economic variables are important:

- market power, as measured by $X_{i, t}^{j} / \sum_{i} X_{i, t}^{j}$, that is the share of a country's exports in a particular sector relative to the total exports in that sector for the reference countries,

- the degree of export specialization, as measured by $X_{i, t}^{j} / \sum_{j} X_{i, t}^{j}$, that is the share of a country's exports in a particular sector relative to that country's total exports, and

- country size, as measured by $\sum_{j} X_{i, t}^{j} / \sum_{i} \sum_{j} X_{i, t}^{j}$, that is the share of a country's total exports relative to total exports for the group of reference countries.

Of these three economic variables the first two are most important for determining violations of Hillman's monotonicity condition, which does not hold if a country has a significantly high degree of market power in combination with a significantly high degree of export specialization. The condition is somewhat less stringent for large countries. To operationalize wether a violation of the Hillman condition is the result primarily of high market power or a high degree of export specialization, we follow the convention of the Netherlands Competition Authority that in principle a market share exceeding 50 percent in a certain sector indicates a dominant position. In the analysis below, consequently, any violations of the Hillman condition will be classified as the result of a high degree of market power if a country's share of exports in that sector relative to the total exports in that sector is at least 50 percent. Otherwise, the violation is attributed to a high degree of export specialization.

We can expect the degree of sector aggregation to affect the extent to which the Hillman condition is violated. At lower levels of aggregation, that is as more sectors are identified, it becomes easier in principle for a country to achieve a dominant position (high market power) in a specific, more narrowly defined sector. Other things equal, this tends to increase the number of violations of the Hillman condition. Other things are, however, not equal as the degree of export specialization falls at lower levels of aggregation, which tends to decrease the number of violations of the Hillman condition. Whether or not the Hillman condition is violated more or less frequently at lower levels of aggregation depends on the interaction between the above two forces and is, therefore, an empirical matter. We have data available at the 4-digit SITC level, and will consequently analyze the connection between the aggregation problem and the Hillman condition at the 1-, 2-, 3-, and 4-digit level. In principle, there are ten 1-digit sectors (0-9), each subdivided in ten 2-digit sectors, etc. In theory, this would lead to 10,000 sectors at the 4 digit level. In practice, we have data available for 1,056 different 
sectors. As a methodological note, to be further addressed in section 5, we perform our calculations only at the appropriate level of aggregation. At the 4-digit level, for example, we indeed focus on the 4-digit level as such and ignore trade flows effectively classified at the 3digit level, such as category $752 \mathrm{~A} / \mathrm{X}$ 'automatic data processing machines \& units thereof' which could refer to trade flows in any of the more detailed 4digit categories 7521, 7522, $7523,7524,7525$ or 7528. Similarly, for our calculations at the 2-digit and 3-digit level, see Feenstra (2000) for further details. ${ }^{6}$ The Balassa index, however, is always calculated relative to a country's total trade flows in any given year, thus including trade flows classified exclusively at higher levels of aggregation.

\section{Violations of the Hillman condition}

Table A1 in the appendix provides a list of the 183 countries included in our analysis. For each of these countries and for all 28 years in our data set (1970-97) we verified if the Hillman condition was met for four different levels of aggregation. ${ }^{7}$ Regarding the number of observations for the period as a whole, our findings can be summarized as follows: on average the Hillman condition is violated for

- 2.6 out of 1,490 observations annually at the 1-digit level,

- 2.8 out of 8,044 observations annually at the 2-digit level,

- 3.1 out of 21,981 observations annually at the 3-digit level, and

- 1.3 out of 31,127 observations annually at the 4-digit level.

This summary, however, does not do justice to the historical development of these violations nor to the importance of the violations as measured by the share of exports not satisfying the Hillman condition. Table 1 provides more detail regarding both these aspects. The bottom line of Table 1 clearly shows that the violations of the Hillman condition as a share of the number of observations is very small and decreases at lower levels of aggregation. It also shows, that as a share of the value of total exports the violations of the Hillman condition are more important and are roughly the same at the 1-, 2-, and 3-digit level (on average more than 3.29 percent), only to decline at the 4-digit level (on average 0.63 percent).

\footnotetext{
${ }^{6}$ We also do not report results on sectors with trade flows below $\$ 100,000$.

${ }^{7}$ Restricting attention to the 168 'real' countries, that is excluding the set of 'not elsewhere specified' countries (see the appendix), does not affect the sectors for which the Hillman condition is violated.
} 
Table 1 Aggregation and share of exports not satisfying the Hillman condition, 1970-97

\begin{tabular}{l|rrrr|rrrr}
\hline \hline & \multicolumn{6}{|c|}{ share of \# of observations $(\%)$} & \multicolumn{5}{c}{ share of value of exports $(\%)$} \\
year & 1-digit & 2-digit & 3-digit & 4-digit & 1-digit & 2-digit & 3-digit & 4-digit \\
\hline 1970 & 0.37 & 0.10 & 0.03 & 0.00 & 3.17 & 6.08 & 5.67 & 3.50 \\
1971 & 0.29 & 0.08 & 0.03 & 0.00 & 2.77 & 3.31 & 5.79 & 0.24 \\
1972 & 0.22 & 0.05 & 0.02 & 0.00 & 2.70 & 2.86 & 4.20 & 0.23 \\
1973 & 0.14 & 0.04 & 0.01 & 0.01 & 2.21 & 2.38 & 2.33 & 0.38 \\
1974 & 0.36 & 0.07 & 0.02 & 0.00 & 10.14 & 8.96 & 7.46 & 0.23 \\
1975 & 0.29 & 0.07 & 0.03 & 0.01 & 6.37 & 6.75 & 6.53 & 0.71 \\
1976 & 0.22 & 0.05 & 0.03 & 0.01 & 6.87 & 7.13 & 9.20 & 0.64 \\
1977 & 0.29 & 0.08 & 0.03 & 0.01 & 7.68 & 10.12 & 9.96 & 4.08 \\
1978 & 0.33 & 0.07 & 0.03 & 0.01 & 6.78 & 8.61 & 7.79 & 4.42 \\
1979 & 0.26 & 0.04 & 0.03 & 0.00 & 5.09 & 4.53 & 7.81 & 0.12 \\
1980 & 0.26 & 0.06 & 0.03 & 0.01 & 8.47 & 8.75 & 8.69 & 0.67 \\
1981 & 0.26 & 0.04 & 0.02 & 0.00 & 8.52 & 7.73 & 8.17 & 0.08 \\
1982 & 0.26 & 0.04 & 0.01 & 0.01 & 6.53 & 5.36 & 5.25 & 0.62 \\
1983 & 0.26 & 0.05 & 0.01 & 0.00 & 5.20 & 4.96 & 4.34 & 0.04 \\
1984 & 0.20 & 0.06 & 0.02 & 0.01 & 3.51 & 4.32 & 3.71 & 0.50 \\
1985 & 0.20 & 0.02 & 0.00 & 0.00 & 1.67 & 1.21 & 0.66 & 0.04 \\
1986 & 0.20 & 0.02 & 0.00 & 0.00 & 1.07 & 0.71 & 0.00 & 0.10 \\
1987 & 0.13 & 0.01 & 0.00 & 0.00 & 0.71 & 0.40 & 0.29 & 0.00 \\
1988 & 0.00 & 0.00 & 0.00 & 0.01 & 0.00 & 0.00 & 0.01 & 0.09 \\
1989 & 0.00 & 0.02 & 0.00 & 0.01 & 0.00 & 0.92 & 0.52 & 0.87 \\
1990 & 0.06 & 0.00 & 0.00 & 0.00 & 1.21 & 0.00 & 0.00 & 0.00 \\
1991 & 0.20 & 0.02 & 0.01 & 0.00 & 0.68 & 0.36 & 0.36 & 0.03 \\
1992 & 0.06 & 0.00 & 0.00 & 0.00 & 0.28 & 0.00 & 0.00 & 0.00 \\
1993 & 0.00 & 0.00 & 0.00 & 0.00 & 0.00 & 0.00 & 0.00 & 0.01 \\
1994 & 0.06 & 0.00 & 0.00 & 0.00 & 0.20 & 0.00 & 0.00 & 0.00 \\
1995 & 0.00 & 0.00 & 0.00 & 0.00 & 0.00 & 0.00 & 0.25 & 0.00 \\
1996 & 0.00 & 0.01 & 0.01 & 0.00 & 0.00 & 0.00 & 0.27 & 0.01 \\
1997 & 0.07 & 0.00 & 0.00 & 0.00 & 0.25 & 0.00 & 0.00 & 0.00 \\
\hline ann. aver. & 0.18 & 0.04 & 0.01 & 0.00 & 3.29 & 3.41 & 3.55 & 0.63 \\
The total number of cases not satisfying the Hillman condition in the period 1970-1997 is 73 at \\
the 1-digit level, 79 at the 2-digit level, 88 at the 3-digit level, an 35 at the 4-digit level. &
\end{tabular}

Figure 1 illustrates the development over time of the violations of the Hillman condition at the four different le vels of aggregation. Panel $a$ depicts the development as a share of the number of observations. It not only shows that this share is low for all four levels of aggregation, never to exceed 0.4 percent in any given year, and that this share decreases for lower levels of aggregation, but also that, for a given level of aggregation, it falls over time, particularly from the second half of the 1980s onwards. The latter is much more pronounced in panel $b$ of Figure 1, which depicts the development over time as a share of the value of exports. Violations of the Hillman condition are very valuable in the period 1970-84, with a peak of 10.14 percent at the 1-digit level in 1974, to become much less important and virtually disappear in the period 1988-97. We now analyze these fluctuations in more detail. 
Figure 1 Development of violations of the Hillman condition over time
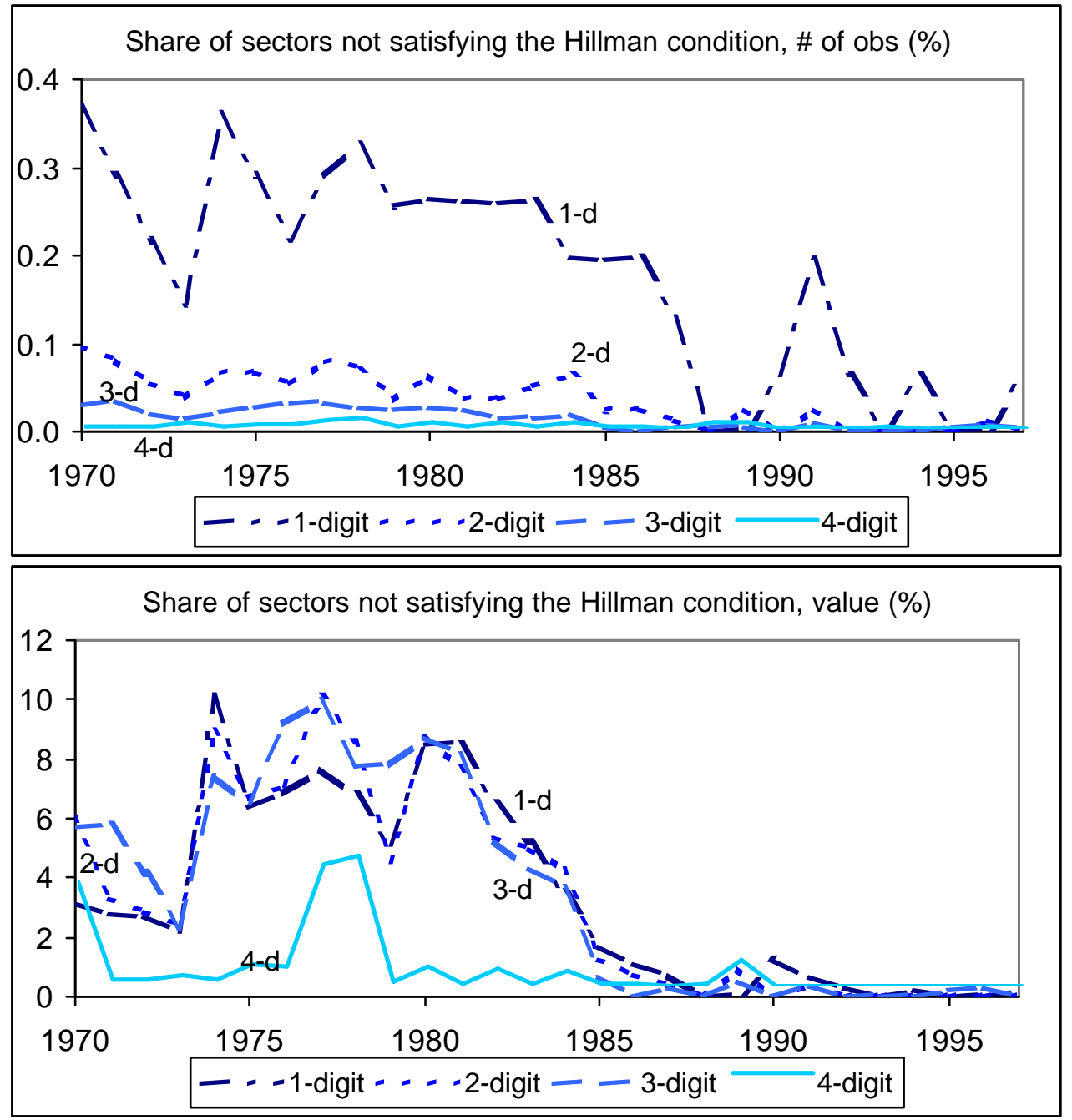

\section{Sectors, countries, and the Hillman condition}

Table 2 lists the 73 observations at the 1-digit level (from a total of 41,733 observations) for which the Hillman condition does not hold. In all cases, the violation is caused by a high degree of export specialization and never the result of high market power at this level of aggregation. With one exception (SITC 0: "food ..." from St. Pierre Miqu) all violations are for SITC 3: "mineral fuels, ...". Again, with one exception (Paraguay), all the SITC 3 violations are from oil-exporting nations, while the majority of the observations takes place in the 1970s and early 1980s. This clearly suggests that the two oil crises of 1973 and 1979 are the main culprits for violations of the Hillman condition. As discussed in section 3, the peak of violations in value terms (10.14\%) occurs in 1974 at the 1-digit level. It involves only five countries: Libya, Iran, Kuwait, Saudi Arabia, and Venezuela. ${ }^{8}$

\footnotetext{
${ }^{8}$ Actually, at first we thought we made a mistake, having in mind the present share in total world trade flows of these five countries, which is below 2 percent. Double-checking everything, and comparing with other sources, revealed that we did not make any mistakes: these five countries indeed controlled
} 
Table 2 Observations not satisfying the Hillman condition; 1-digit SITC, 1970-1997

\begin{tabular}{|c|c|c|c|}
\hline code & description & country & years \\
\hline 0 & Food and live animals chiefly for food & St Pierre Miqu & 79 \\
\hline $3^{--}$ & Mineral fuès, lubricants and related materials & Algeria & $\overline{79} \overline{8} \overline{7}, \overline{9} \overline{1}, \overline{9} \overline{9} \overline{9}, \overline{9} \overline{7}$ \\
\hline & & Libya & $70-83,85,86$ \\
\hline & & Venezuela & 70,74 \\
\hline & & Kuwait & $70-72,74$ \\
\hline & & Qatar & 70,71 \\
\hline & & Saudi Arabia & $70-84,90$ \\
\hline & & Iran & $74-78,83$ \\
\hline & & Oman & 75 \\
\hline & & Iraq & $77,78,80,85-87$ \\
\hline & & Un Arab Em & 78 \\
\hline & & Nigeria & $81,82,84,91$ \\
\hline & & Paraguay & 91 \\
\hline
\end{tabular}

Table 3 Observations not satisfying the Hillman condition; 2-digit SITC, 1970-1997

\begin{tabular}{|c|c|c|c|}
\hline code & description & country & years \\
\hline 06 & Sugar, sugar preparations and honey & Cuba & $75-78$ \\
\hline \multirow{9}{*}{$3 \overline{3}$} & Petroleum, petroleum products and & Libya & $\overline{0}-\overline{8} \overline{1}, \overline{3}, \overline{8} \overline{6}^{-}$ \\
\hline & related material & Venezuela & 70 \\
\hline & & Kuwait & $70-72,74$ \\
\hline & & Qatar & 70,71 \\
\hline & & Saudi Arabia & $70-84$ \\
\hline & & Iraq & $71,77,78,80,83-89$ \\
\hline & & Iran & $74-78,83,84$ \\
\hline & & Oman & 75 \\
\hline & & Nigeria & $81,82,84,85,91$ \\
\hline $35^{-}$ & Electric current & Paraguay & $9 \overline{1} \cdots \cdots-1$ \\
\hline $68-$ & Non-ferrous metals & Zambia & $\overline{70}-\overline{74}$ \\
\hline$\overline{9} \overline{3}^{-}$ & $\begin{array}{l}\text { Special transactions \& commod., not } \\
\text { class. to kind }\end{array}$ & South Africa & $80^{---1}$ \\
\hline \multirow[t]{5}{*}{$\overline{9} \overline{9}^{-}$} & Non-identified products & Former ŪSSTS & $\overline{7} 0, \overline{7} \overline{7}, \overline{78}$ \\
\hline & & Zimbabwe & 79 \\
\hline & & Romania & $80,82,84 *$ \\
\hline & & East Germany & 89 \\
\hline & & Reunion & 96 \\
\hline
\end{tabular}

Table 3 lists the 79 observations at the 2-digit level (from a total of 225,230 observations) for which the Hillman condition does not hold. With one exception ("non-identified products" exported from Romania in 1984) all violations are caused by a high degree of export specialization and not by high market power. Relative to the information given in Table 2, we see some more detail. The violations for SITC 3 for the oil-exporting countries are contributed to SITC 33 "petroleum, ...", while it is related to SITC 35 "electric current" for 
Paraguay. Apart from the uninformative "non-identified products" category, which may refer to clandestine trade, arms deals, trade with nations without official trade ties, trade flows which have not been properly classified, etc., there are only three new items: SITC 06 "sugar, ..." exports from Cuba, SITC 68 "non-ferrous metals" exports from Zambia, and SITC 93 "special transactions, ..." exports from South Africa.

Table 4 Observations not satisfying the Hillman condition; 3-digit SITC, 1970-1997

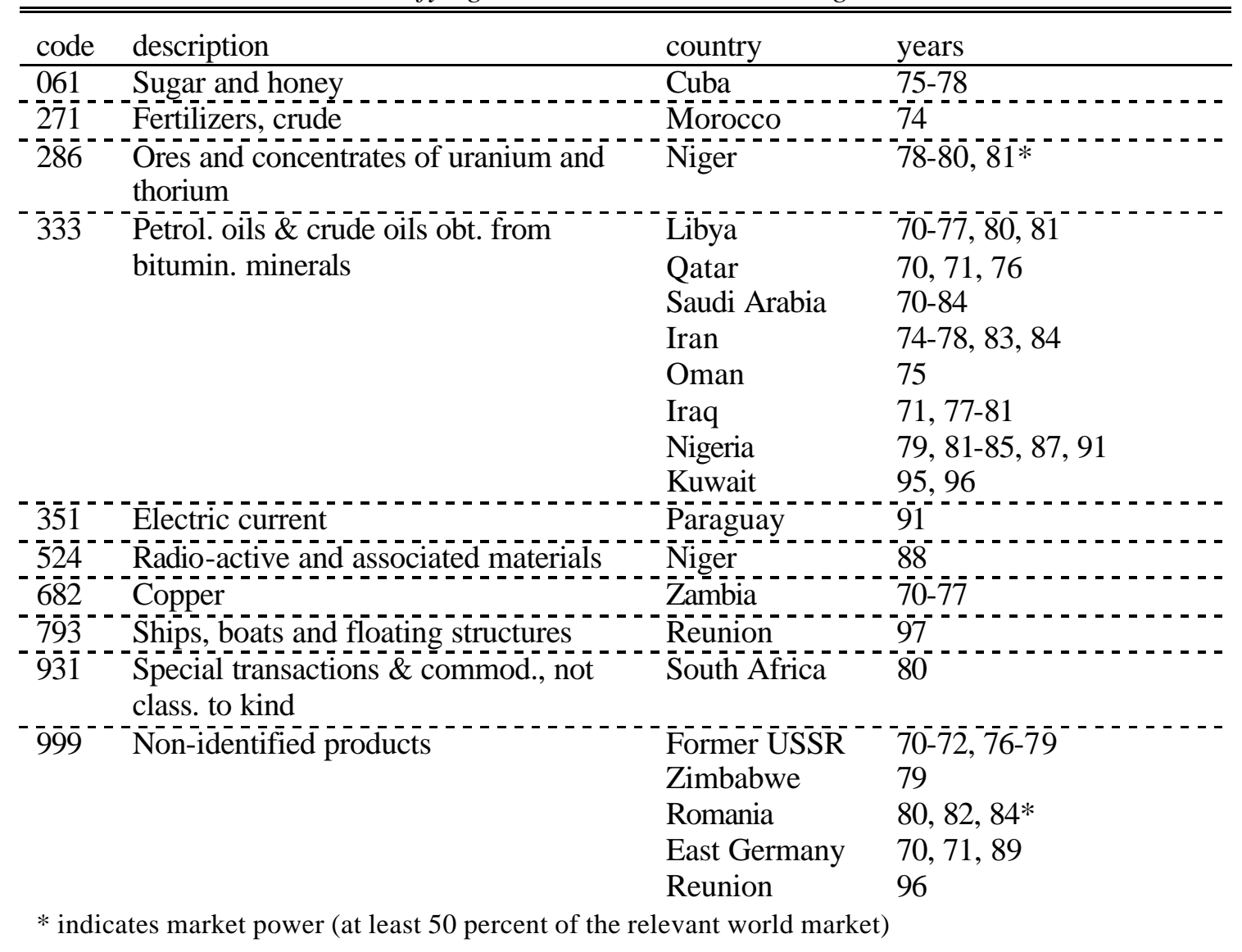

Table 4 lists the 88 observations at the 3-digit level (from a total of 615,467 observations) for which the Hillman condition does not hold. With two exceptions (Romania [see Table 3] and SITC 286 "ores ... uranium ..." exports from Niger in 1981) all violations are caused by a high degree of export specialization and not by high market power. Relative to the information given in Table 3 we again see somewhat more detail. The SITC 33 violations are caused by SITC 333 "petrol. oils ...", Cuba's violation is related to SITC 061 "sugar and honey", Zambia's "non-ferrous metals" is related to SITC 682, "copper", while SITC 351 "electric current" and SITC 931 "special transactions ..." are actually 3-digit classifications. The newcomers are radio-active for Niger (SITC 286 and SITC 524), but not for Morocco (SITC 271 "fertilizers, crude") and Reunion (SITC 793 "ships, boats ..."). 
Figure 2 Level of aggregation and share of total trade covered

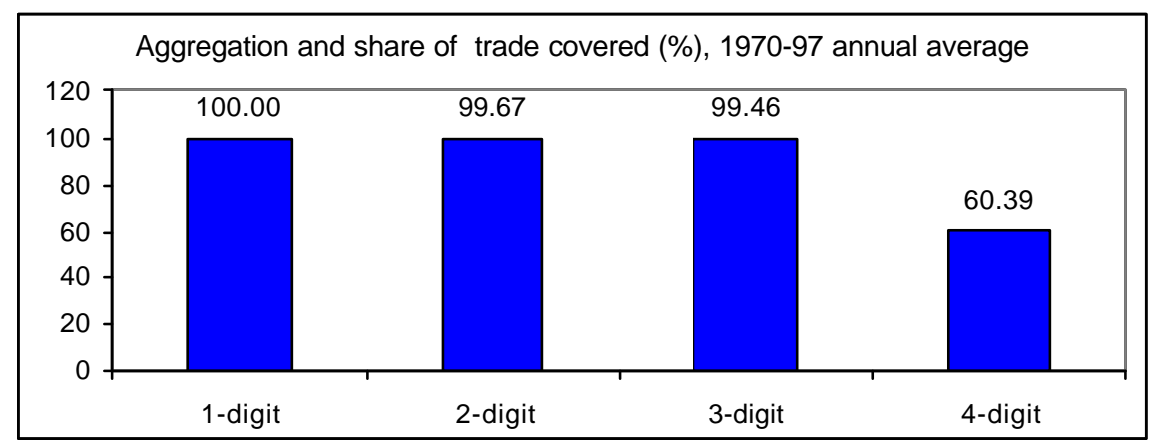

An important advantage of analyzing trade flows in general and comparative advantage in particular at lower, more detailed levels of aggregation is the increased coherence and homogeneity of the specific markets analyzed, and therefore the more precise identification of a country's strong and weak export sectors. An important disadvantage is that some of the information is not available at lower levels of aggregation, such that a lower share of total trade flows is represented by the data. As illustrated in Figure 2, this disadvantage of lower representation at lower levels of aggregation is not very important if we go from the 1-digit to the 2-digit level or if we go from the 2-digit to the 3-digit level. It is, however, a major problem when we go from the 3-digit to the 4digit level as many trade flows (about 40 percent of total trade flows) are not disaggregated to the 4-digit level. We have to keep this in mind when studying Table 5, which lists the 35 observations at the 4digit level (from a total of 871,543 observations) for which the Hillman condition does not hold.

Table 5 Observations not satisfying the Hillman condition; 4-digit SITC, 1970-1997

\begin{tabular}{|c|c|c|}
\hline code description & country & years \\
\hline 0611 Sugars, beet and cane, raw, solid & Cuba & $75-77,78^{*}$ \\
\hline$\overline{2} \overline{4} \overline{9}$ Pitprops, poles, piling, posts \& other wood in rough & Indōonesia & $73 *-1-$ \\
\hline$\overline{2} \overline{1} \overline{4}-$ Roasted iron pyrites, whether or not agglomerated & Brazil & $86^{*}, 88^{*} \cdots$ \\
\hline & Papua N. Guin. & $93 * \ldots$ \\
\hline$\overline{2} \overline{8} \overline{3} \bar{A}^{-}$Āuminium ores and concentrates (includ.alumina) & Guinea & $78,82-85,91$ \\
\hline Petroleum oil nren \& & Jamaica & ـ \\
\hline $68211^{-}$Copper and copper alloys, refined or not, unwrought & nambia & $88^{*}, 89$ \\
\hline$\overline{9} \overline{9} \overline{9} \overline{9}^{-}$Non-identified products & Former USS $\overline{\mathrm{SS}} \overline{\mathrm{R}}^{-}$ & $-\overline{70}, \overline{7} \overline{7}, \overline{8} \overline{8}^{---}$ \\
\hline & Zimbabwe & 79 \\
\hline & Romania & $80,82,84 *$ \\
\hline & East Germany & 89 \\
\hline & Reunion & 96 \\
\hline
\end{tabular}

* indicates market power (at least 50 percent of the relevant world market)

SITC 9999 "non-identified products" is most prominent in Table 5. We have encountered it before in Tables 3 and 4 for the 2 and 3 digit sectors. Indeed, one could argue that it is actually an 'aggregate' sector consisting of a broad range of miscellaneous products, but it is formally classified as a 4digit sector. With the exception of Cuba's sugar (SITC 0611) and 
Zambia's copper (SITC 6821) all other entries in Table 5 are new, mainly because the more precise sector definition makes it possible for countries to achieve a dominant market share. In fact, 8 of the 35 violations of the Hillman condition (23 percent) is attributed to market power, see Table 5 for details.

\section{Aggregation and the Hillman condition}

Tables 2, 3, 4, and 5 above list violations of the Hillman condition at the 1-, 2-, 3-, and 4-digit level, respectively. As explained in section 2, these tables are 'clean' by analyzing only trade flows at the appropriate level of aggregation. The Hillman condition is not satisfied if a country has a high market power in a certain sector, with a pure monopoly as the most extreme example, in which case the Hillman condition does not hold. This issue is, however, clearly related to the aggregation / data-classification problem. To illustrate this, we recalculated the Hillman condition for all countries, sectors, and years at the 3-digit level, this time including the 1-digit and 2-digit 'aggregates' as reported at the 3-digit level (for ease of notation the aggregates are defined using a ' 0 ' or ' 00 ' at the end).

Table 6 lists the 109 aggregates at the 3-digit level that do not satisfy the Hillman condition. In most cases, namely 85 out of 109 (or 78 percent), this is the result of the country having a reported 'monopoly'. In all cases the violation is attributed to market power (the market share is actually at least 92.6 percent). Clearly, the Hillman condition turns out to be most useful in such instances at identifying peculiarities, in this case a data-classification problem. In the 1980s and 1990s, for example, Germany frequently is the only country classifying products at the 'miscellaneous' 1-digit level, the categories '600', '700', '800', and 900' in Table 6, resulting in an artificial monopoly readily identified by the Hillman condition. Similarly, while most other countries take the trouble to identify if the exported 'dairy products and birdseggs' are either 'milk and cream', 'butter', 'cheese and curd', or 'eggs and yolks, fresh, dried, or otherwise preserved', Hungary simply lists them as 'dairy products and birdseggs'. Although not leading to a monopoly for Hungary in the years 78-83, the Hillman condition does pick up this classification problem, as it does for Hungary's classification of sectors '010', '040', and '050', see Table 6. 


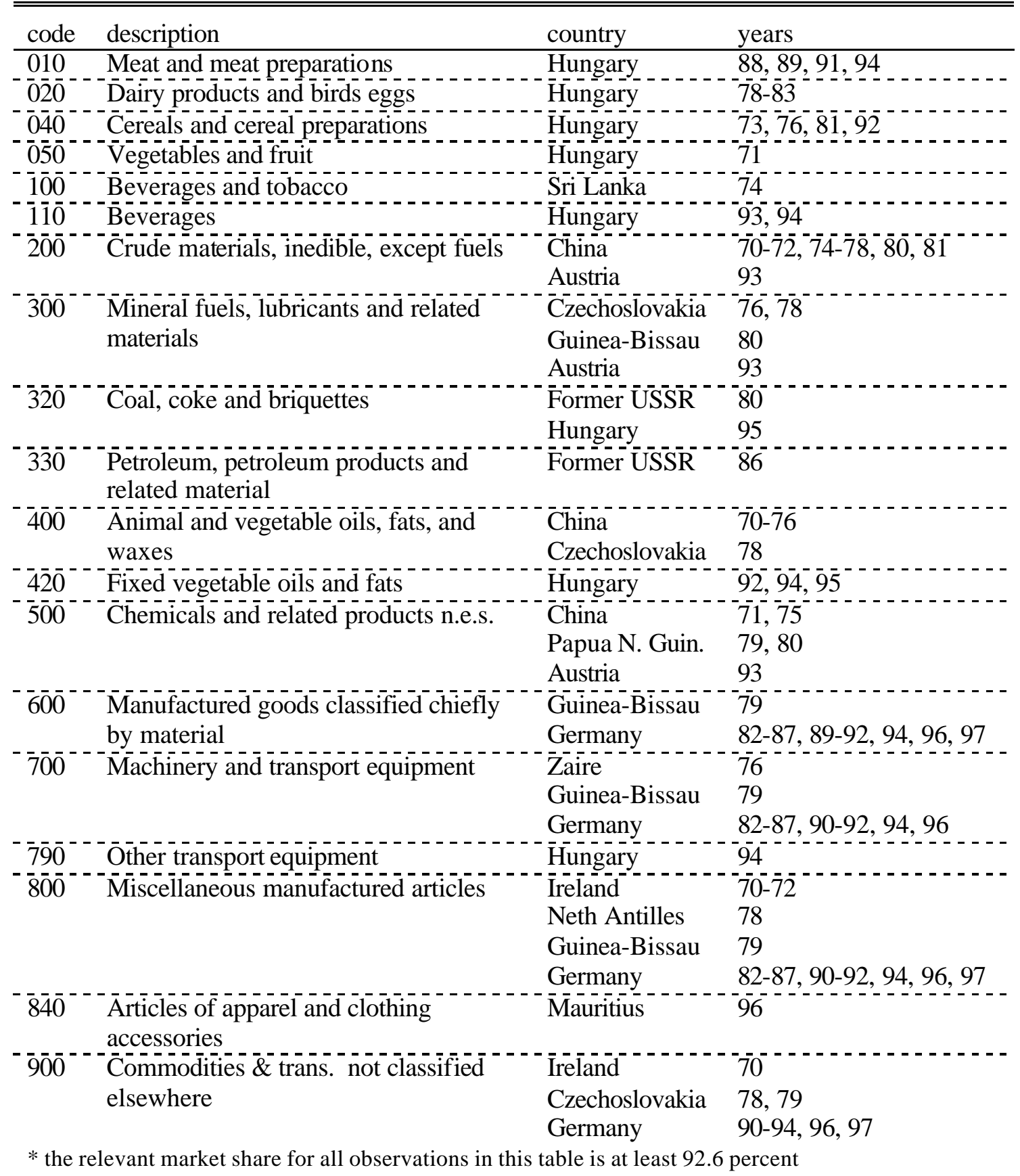

\section{Conclusions}

We analyze the empirical violation of the Hillman condition, a necessary and sufficient condition for the correspondence between comparative advantage as measured by the Balassa index and pre-trade relative prices. Hillman's monotonicity condition, which is somewhat less stringent for large countries, does not hold if a country has a significantly high degree of market power in a certain sector, in combination with a significantly high degree of export specialization. Our comprehensive data set of annual bilateral trade flows for 1,056 4digit SITC sectors between 183 countries over 28 years allows us to thoroughly investigate the 
Hillman condition for virtually all countries of the world, over an extended period of time, for many sectors, and for different levels of aggregation.

For the period 1970-97 as a whole, we find that the Hillman condition is violated on average for less than 4 percent of the value of exports and fewer than 0.2 percent of the number of observations. This average is, however, a poor indicator, as we also find considerable fluctuations over time, with high violations in the period 1970-84 (up to 10 percent of the value of world exports) and low violations in the period 1988-97 (on average less than 0.26 percent of the value of world exports). This remarkable difference is mostly caused by the 1973 and 1979 oil crises. As a share of the number of observations, violations of the Hillman condition are rare and occur less frequently at lower levels of aggregation. As a share of the value of exports, violations of the Hillman condition are more important and represent about the same share of exports at the 1-, 2-, and 3-digit level, only to fall significantly going to the 4-digit level (when the share of exports covered also drops significantly). In virtually all cases at the 1-, 2-, and 3-digit level, violations of the Hillman condition are caused by a high degree of export specialization (think of the oil-exporting countries, Cuba's sugar, and Zambia's copper). Only at the 4 digit level, a substantial share of the violations are caused by a high degree of market power. A brief investigation at the 3-digit level shows that the Hillman condition is also rather effective at identifying data-classification problems. We therefore argue that it would be wise for empirical studies into comparative advantage to henceforth include an empirical evaluation of the Hillman condition as a standard diagnostic test (as the analysis above shows that the condition is useful for identifying anomalies), and to restrict attention to those industries that satisfy the Hillman condition. 


\section{References}

Amity, M. (1999), "Specialization patterns in Europe," Weltwirtschaftliches Archiv, 135, 573593.

Balassa, B. (1965), "Trade liberalization and 'revealed' comparative advantage," The Manchester School of Economic and Social Studies 33: 92-123.

Bojnec, S. (2001), “Trade and revealed comparative advantage measures: regional and central and east European agricultural trade," Eastern European Economics, 39 (2), 72-98.

Feenstra, R. C. (2000), World trade flows; 1980 - 1997, Institute of Governmental Affairs, University of California, Davis.

Fertö, I., and L.J. Hubbard (2003), "Revealed comparative advantage and competitiveness in Hungarian Agri-food sectors,” World Economy, 26 (2), 247-259.

Hillman, A.L. (1980), "Observations on the relation between 'revealed comparative advantage' and comparative advantage as indicated by pre-trade relative prices," Weltwirtschaftliches Archiv, 116, No. 2, 315 - 21.

Hinloopen, J. and van Marrewijk, C. (2001), "On the empirical distribution of the Balassa index", Weltwirtschaftliches Archiv, 137, No. 1, 1- 35.

Hinloopen, J., and C. van Marrewijk (2004), "On the dynamics of Chinese comparative advantage," mimeo Tinbergen Institute.

Liesner, H.H. (1958), "The European Common Market and British industry," Economic Journal 68: 302-316.

Marchese, S., and F. Nadal De Simone (1989), "Monotonicity of indices of 'revealed' comparative advantage: empirical evidence on Hillman's condition," Weltwirtschaftliches Archiv 125, 158 - 167.

Porter, M. (1990), The competitive advantage of nations, MacMillan, London.

Proudman, J. and S. Redding (1998), "Persistence and mobility in international trade," in: J. Proudman and S. Redding (eds.), Openness and growth, Bank of England, Chapter 2.

Proudman, J. and S. Redding (2000), "Evolving patterns of international trade," Review of International Economics, 8 (3), pp. 373-396. 


\begin{tabular}{|c|c|c|c|}
\hline \multicolumn{4}{|c|}{ Appendix Table A1 List of countries } \\
\hline South Africa & Somalia & French Guiana & Mongolia \\
\hline Algeria & Zimbabwe & Guyana & Vietnam \\
\hline Liby Arab Jm & Togo & Panama & Asia Cpe NES \\
\hline Morocco & Uganda & Surinam & Belgium Lux. \\
\hline Western Sahara & Untd Rp Tanzania & Rest America NES & Denmark (Incl Faroe Islds) \\
\hline Sudan & Burkina Faso & Israel & France \\
\hline Tunisia & Zambia & Japan & Germany \\
\hline Egypt & Other Africa NES & Bahrain & Greece \\
\hline North Africa NES & Canada & Cyprus & Ireland \\
\hline Cameroon & Usa & Iran & Italy \\
\hline Central Afr. Rep. & Bermuda & Iraq & Netherlands \\
\hline Chad & Greenland & Jordan & Portugal \\
\hline Congo & St Pierre Miqu & Kuwait & Spain \\
\hline Gabon & Argentina & Lebanon & United Kingdom \\
\hline Ceuca NES & Bolivia & Oman & EEC NES \\
\hline Angola & Brazil & Qatar & Austria \\
\hline Br.Ind.Oc.Tr & Chile & Saudi Arabia & Finland \\
\hline Burundi & Colombia & Fm Dem Yemen & Iceland \\
\hline Comoros & Ecuador & Syrn Arab Rp & Norway \\
\hline Zaire & Mexico & Untd Arab Em & Sweden \\
\hline Benin & Paraguay & Turkey & Switzerland \\
\hline Eq. Guinea & Peru & Fm Yemen & Efta NES \\
\hline Ethiopia & Uruguay & Yemen & Gibraltar \\
\hline Fr.So.Ant.Tr & Venezuela & Middle East NES & Malta \\
\hline Djibouti & LAIA NES & Afghanistan & Other Eur NES \\
\hline Gambia & Costa Rica & Bangladesh & Albania \\
\hline Ghana & El Salvador & Bhutan & Bulgaria \\
\hline Guinea & Guatemala & Brunei & Czechoslovakia \\
\hline Cote D'ivoire & Honduras & Myanmar (Burma) & Fm German Dm Rp (East) \\
\hline Kenya & Nicaragua & Cambodia & Hungary \\
\hline Liberia & CACM NES & Sri Lanka & Poland \\
\hline Madagascar & Bahamas & Hong Kong & Romania \\
\hline Malawi & Barbados & India & Fm Eur Cpe NES \\
\hline Mali & Cayman Islds & Indonesia (Incl Macau) & $\begin{array}{l}\text { Fm Yugoslavia (Incl } \\
\text { Croatia, Slovenia) }\end{array}$ \\
\hline Mauritania & Cuba & Korea Rp (South) & Fm Ussr \\
\hline Mauritius & Dominican Rp & Laos P.Dem.R & Australia \\
\hline Mozambique & $\begin{array}{l}\text { Guadeloupe (Incl } \\
\text { Martinique) }\end{array}$ & Malaysia & New Zealand \\
\hline Niger & Haiti & Maldives & Solomon Islds \\
\hline Nigeria & Jamaica & Nepal & Fiji \\
\hline $\begin{array}{l}\text { Guinea-Bissau (incl Cape } \\
\text { Verde) }\end{array}$ & Neth Antilles & Pakistan & $\begin{array}{l}\text { Kiribati (incl solomon } \\
\text { islds, tonga, tuvalu) }\end{array}$ \\
\hline Reunion & $\begin{array}{l}\text { St Kitts Nev (Incl Dom. } \\
\text { Mont, St Luca,St Vin.*) }\end{array}$ & Philippines & $\begin{array}{l}\text { New Caledonia (Incl Fr } \\
\text { Polynesia, Vanuata) }\end{array}$ \\
\hline Rwanda & Trinidad-Tobago & Singapore & Papua N.Guinea \\
\hline St.Helena & Turks Caicos Isl & Thailand & Oth. Oceania NES \\
\hline Senegal & Caribbean NES & Taiwan & Areas NES \\
\hline Seychelles & Belize & China & Unknown Partner \\
\hline Sierra Leone & Falkland Isl & Korea D P Rp (North) & (* and Grenada) \\
\hline
\end{tabular}

